\title{
Tender Evaluation Improvement at PT. X Using Analytical Hierarchy Process
}

\author{
Athina S Ratum*1, Chikita Lestari Sianipar ${ }^{1}$, Andira Taslim ${ }^{1}$ \\ 1) Faculty of Engineering, Industrial Engineering Department, President University \\ Jl. Ki Hajar Dewantara \\ Kota Jababeka,Cikarang, Bekasi - Indonesia 17550 \\ Email: athina.sakina@president.ac.id
}

\begin{abstract}
A project is part of the activity done by the company in order to achieve its business goal. One of the activities inside a project is tendering to ensure the availability of the resources needed for the project is fulfilled. PT. $X$ is one of the companies that implement the tendering process to achieve its business goal. One of the operations that require the tendering process is the security operation. The tender announcement is made public for any vendors able to fulfilled the requirement can apply for the tender and follow the selection process. The selection process is conducted by the procurement committee and the contract engineer. They determined the tender evaluation criteria and give scores to each of the criteria. In the current condition, the determination of the weight is prone to subjectivity due to the non-existence of any quantitative method in the decision-making process. This study proposes the use of the Analytical Hierarchy Process (AHP) as a tool to help the company to determine the criteria, sub-criteria, and each of the weights as the quantitative method. This method reduces the subjectivity factor and ensures a structured decision-making framework. The winner of the tender from this study and the current condition are the same. However, the final score is different, and the vendor with the lowest score is also different. This difference is due to the different weights in the current condition and this study.
\end{abstract}

Keywords: Analytical Hierarchy Process, tender, decision making, scoring method, vendor.

\section{ABSTRAK}

Proyek adalah bagian dari kegiatan yang dilakukan oleh perusahaan untuk mencapai tujuan bisnisnya. Salah satu kegiatan dalam sebuah proyek adalah tender untuk memastikan terpenuhinya ketersediaan sumber daya yang dibutuhkan untuk proyek. PT. X merupakan salah satu perusahaan yang melaksanakan proses tender untuk mencapai tujuan bisnisnya. Salah satu operasi yang memerlukan proses tender adalah operasi pengamanan. Pengumuman tender dilakukan untuk umum sehingga vendor yang memenuhi persyaratan dapat mengajukan tender dan mengikuti proses seleksi. Proses seleksi dilakukan oleh panitia pengadaan dan teknisi kontrak. Mereka menentukan kriteria evaluasi tender dan memberikan skor untuk masing-masing kriteria. Kondisi saat ini, penentuan bobot rentan terhadap subjektivitas karena tidak adanya metode kuantitatif dalam proses pengambilan keputusan. Penelitian ini mengusulkan penggunaan Analytical Hierarchy Process (AHP) sebagai alat untuk membantu perusahaan dalam menentukan kriteria, subkriteria, dan masing-masing bobot sebagai metode kuantitatif. Metode ini mengurangi faktor subjektivitas dan memastikan kerangka kerja pengambilan keputusan yang terstruktur. Pemenang tender dari studi ini dan kondisi saat ini sama. Namun, skor akhir berbeda, dan vendor dengan skor terendah juga berbeda. Perbedaan ini disebabkan oleh perbedaan bobot pada kondisi saat ini dan penelitian ini.

Kata Kunci: Analytical Hierarchy Process, tender, decision making, scoring method, vendor.

\section{Introduction}

PT. $X$ is an oil and gas company that operates in Indonesia. To support its operation, PT. $X$ has several projects. A project is a temporal set of works to develop a one-of-a-kind outcome, service, or product (Project Management Institute, 2017). Each of the projects is being managed through the project management knowledge area. One of the knowledge areas is procurement management. Project Management Institute (PMI) defines procurement management as the required process to acquire items, services, or results from resources outside the project team (2017). An efficient process of procurement is critical for a company's survival and 
profitability, and the effectiveness of the public sector to gather resources for social expenditures and/or cut taxes (Dimitri, Piga, \& Spagnolo, 2006)

One of the methods to find the resources is through tender. Tender is a series of activities to provide goods and services by creating fair competition among equal and qualified providers of goods/services, based on certain methods and procedures that have been determined and followed by the relevant parties in accordance with the principle so that the best provider is chosen (Ervianto, 2005). PT. X has used tender as a way to fulfill their resources, specifically in the Security Operation.

The current process of tender in PT. X starts with internal preparation, where the procurement committee and the contract engineer (Contract and Procurement Division) decide who is in charge of the tender and make the tender's draft procedure requirement, including the criteria evaluation and the draft of tender advertisement. The next step is the announcement \& registration, where the procurement committee publishes the announcement through the announcement board, website, and other media. The announcement provides guidance related to tender registration.

The third step is pre-qualification where the vendors are evaluated for their scope of work and capability. The next step is the pre-bid meeting where the procurement committee and the vendors (bidders) meet to discuss anything related to the tender requirement that needs to be evaluated. The fifth step is the bid opening where the bidders bring documents (according to the tender requirement) in an envelope and it shall be opened during that time. The sixth step is the procurement committee evaluates the bidder based on the submitted document. The evaluation starts with an internal discussion on giving the weight to the predetermined criteria, and then the procurement committee provides the score to each bidder. Currently, the determination of the weight for each criterion only follows the feeling of the committee, which leads to subjectivity.

The seventh step is determining the winner by calculating the weight and score of each bidder. The bidder who received the highest total score is the winner of the tender. This result should be approved by the President Director of the company. Once the winner is approved, the winner will be announced to the public.

The subjectivity in the sixth step leads to an improper determination of the criteria weight that leads to the decision to choose the incorrect winner for tender. This is reflected in the high number of projects that were neglected due to the inability of the vendor (the winner of the tender) to perform in accordance with the agreement.

This research will focus on helping PT. $X$ in the evaluation process of the technical document by applying one of the multi-criteria decision-making (MCDM) tools, the Analytical Hierarchy Process (AHP), to the elements appraisal value system and the assessment of criteria based on the criteria from the procurement committee (Merit Point System). Various studies in the different fields consider AHP as the most common and effective MCDM method (Waris, et al., 2019). AHP is built to deal with both the rational and intuitive aspects of choosing the best option from a set of options based on a set of criteria (Saaty \& Vargas, 2012). Another purpose of AHP is to assist analysts to discover the optimal alternative by addressing each component of the failure in the hierarchy and reducing difficult choice issues methodically and analytically (Khaira \& Dwivedi, 2017).

\section{Methods}

\subsection{Initial Observation}

An observation is made in the Contract and Procurement Division of PT. X. The initial observation aims to identify the current condition of the tender evaluation process in order to identify the suitable tools for the improvement.

\subsection{Problem Identification}

There is no quantitative method in determining the weight of each criterion to evaluate the tender document. The weight of each criterion is determined by the procurement committee and contract engineer subjectively. 


\subsection{Literature Study}

After the problem is being identified, a literature search is conducted to find a suitable method related to the decision-making process. Moreover, it is used as the basis of the steps to conduct the research. The literature search is obtained from books, journals, and other sources related to the research topic.

\subsection{Data Gathering}

The data is gathered through two processes, interview, and database review. The interviewee is the people in charge of the tendering process, such as the procurement committee, contract engineer, and manager of the contract service. The database review is looking through the data of the ongoing tender process (technical assessment, criteria to choose the winner of tender) based on the approval of the contract \& procurement division.

\subsection{Analysis}

The next step is to identify and classify the criteria that have been used to determine the winner. Then, analyze the collected data, and give weight to the criteria based on the preference of the people in charge of the tendering process. After that, the weight of each criterion is evaluated considering the goal, while the subcriteria are evaluated considering the criteria. The difference between the winner (using the proposed method) and the current winner will be analyzed also.

\subsection{Conclusion and Recommendation}

Based on the research, the conclusion can be derived related to the criteria, sub-criteria, and weight. Recommendation for further research is also discussed in this section.

\section{Result and Discussion}

\subsection{Identification of Criteria and Sub-Criteria}

An interview and discussion were conducted with the Contract Engineer (1 person) and the Procurement Committee ( 2 people). The questions that are being discussed are related to the existing methodology to evaluate the tender, the current way to decide the weight of criteria and sub-criteria, and the person who is responsible for the tender. Once the criteria and the sub-criteria are determined, the hierarchy is constructed. The hierarchy of the tender evaluation can be seen in Figure 1.

\subsubsection{Project Management}

The criteria of project management (PM) give insight into the organizational structure and personnel structure of the vendors. It also shows the working experiences, the job description, and responsibilities. The sub-criteria are organization structure (PM1), project operational organization chart (PM2), working facility and location (PM3), experiences for security services (PM4), employment agreement (PM5), payroll management system (PM6), personnel database (PM7), and SOP for schedule planning (PM8).

\subsubsection{Security Operation and Strategy}

The security operation and strategy (SOS) give insight into the vendors' existing procedures related to the security operation and the vendors' strategy to do the tender. The sub-criteria are SOP static and patrol guards (SOS1), SOP escort (SOS2), SOP investigation (SOS3), SOP emergency response procedures (SOS4), local community relation and approach (SOS5), intelligence and confidential issues (SOS6).

\subsubsection{Equipment}

The equipment (EQP) criteria give insight into the vendors' equipment specifications when doing the operation by providing the information in a brochure or catalog. The sub-criteria are PPE specification (EQP1), brochure or product catalog (EQP2), transportation proposal (EQP3). 


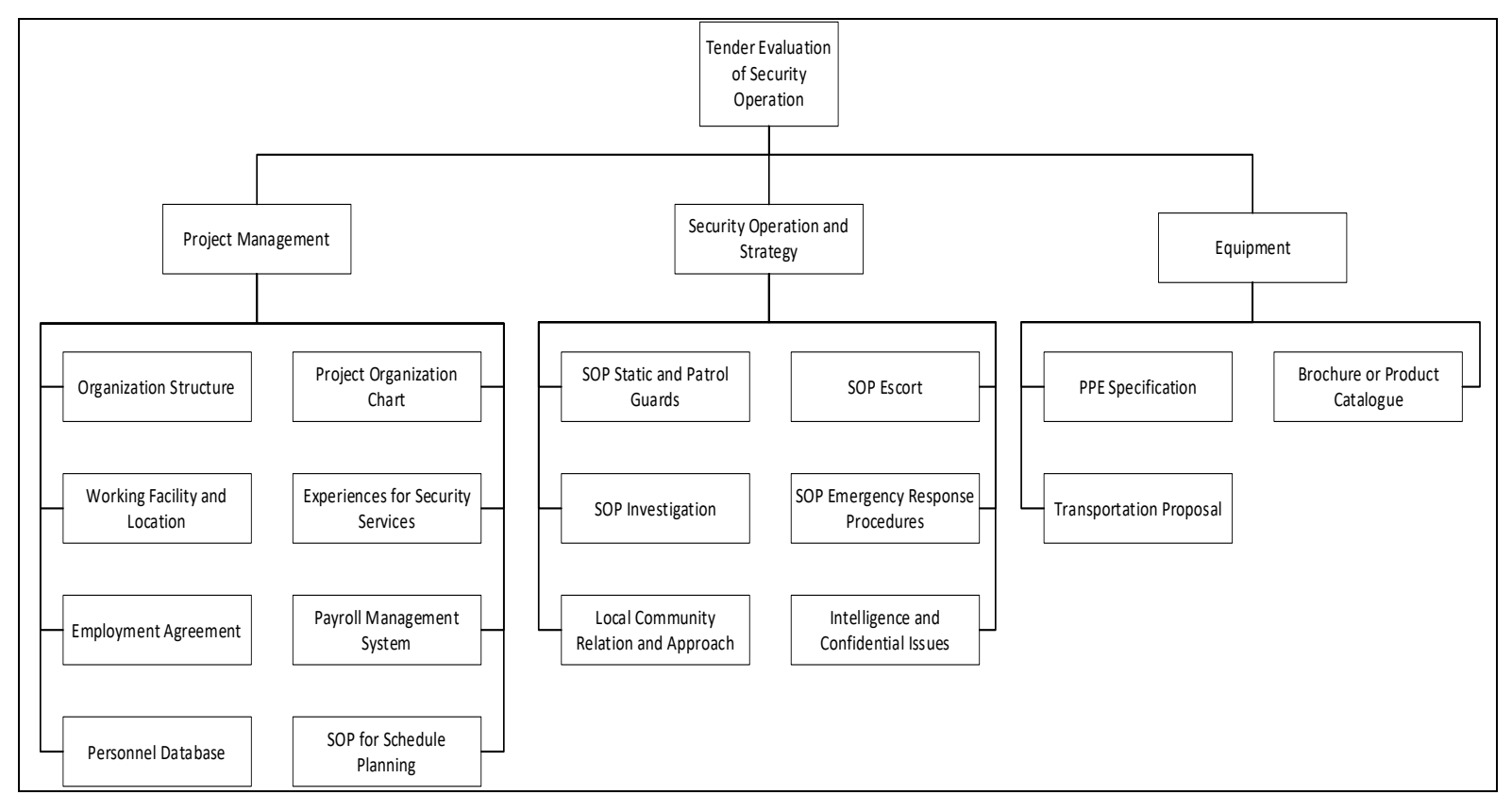

Figure 1. Hierarchy of the tender evaluation

\subsection{Pairwise Comparison Matrix}

Once the criteria and sub-criteria have been determined, another questionnaire was distributed to the same people to find the preference on which criteria and sub-criteria are the most important. Respondents were asked to choose between two criteria that are the more important and give a rate on the importance. The rates value is between 1 to 9 where 1 represents equal importance, while 9 represents absolute importance. The data then being calculated through pair-wise comparison.

The result of the pairwise comparison for the criteria is listed in the matrix in Table 1 . The example of a pairwise comparison for the sub-criteria can be seen in Table 3. The final matrix for the criteria and subcriteria is constructed through the geometric mean of the three respondents and can be seen in Table 2, Table 4, Table 5, and Table 6.

Table 1 Preference on Criteria

\begin{tabular}{|l|l|l|l|l|l|l|l|l|l|l|l|}
\hline Criteria & PM & SOS & EQP & Criteria & PM & SOS & EQP & Criteria & PM & SOS & EQP \\
\hline PM & 1 & $1 / 5$ & $1 / 5$ & PM & 1 & 5 & $1 / 7$ & PM & 1 & $1 / 5$ & 4 \\
\hline SOS & 5 & 1 & 5 & SOS & $1 / 5$ & 1 & $1 / 7$ & SOS & 5 & 1 & 7 \\
\hline EQP & 5 & $1 / 5$ & 1 & EQP & 7 & 7 & 1 & EQP & $1 / 5$ & $1 / 7$ & 1 \\
\hline \multicolumn{8}{|c|}{ Second Person } \\
\hline
\end{tabular}

Table 2 Final Matrix of Preference Criteria

\begin{tabular}{|l|c|c|c|}
\hline & PM & SOS & EQP \\
\hline PM & 1 & 0.585 & 0.485 \\
\hline SOS & 1.710 & 1.000 & 1.710 \\
\hline EQP & 1.913 & 0.585 & 1.000 \\
\hline Sum & 4.623 & 2.170 & 3.195 \\
\hline
\end{tabular}


Table 3 Preference on Sub-Criteria of Project Management

\begin{tabular}{|l|c|c|c|c|c|c|c|c|}
\hline $\begin{array}{l}\text { Sub- } \\
\text { Criteria }\end{array}$ & PM1 & PM2 & PM3 & PM4 & PM5 & PM6 & PM7 & PM8 \\
\hline \multicolumn{7}{|c|}{ First Person } \\
\hline PM1 & 1 & 7 & 7 & 7 & 7 & 7 & 7 & 7 \\
\hline PM2 & $1 / 7$ & 1 & $1 / 7$ & 6 & 6 & $1 / 7$ & $1 / 7$ & $1 / 7$ \\
\hline PM3 & $1 / 7$ & 7 & 1 & 9 & 8 & 8 & 8 & 9 \\
\hline PM4 & $1 / 7$ & $1 / 6$ & $1 / 9$ & 1 & 9 & $1 / 9$ & 5 & 5 \\
\hline PM5 & $1 / 7$ & $1 / 6$ & $1 / 8$ & $1 / 9$ & 1 & $1 / 6$ & $1 / 6$ & $1 / 6$ \\
\hline PM6 & $1 / 7$ & 7 & $1 / 8$ & 9 & 6 & 1 & 7 & 7 \\
\hline PM7 & $1 / 7$ & 7 & $1 / 8$ & $1 / 5$ & 6 & $1 / 7$ & 1 & $1 / 9$ \\
\hline PM8 & $1 / 7$ & 7 & $1 / 9$ & $1 / 5$ & 6 & $1 / 7$ & 9 & 1 \\
\hline \multicolumn{7}{|c|}{ Second Person } \\
\hline PM1 & 1 & $1 / 4$ & 6 & $1 / 4$ & $1 / 2$ & $1 / 4$ & 1 & $1 / 3$ \\
\hline PM2 & 4 & 1 & 1 & 1 & 1 & $1 / 3$ & 3 & $1 / 3$ \\
\hline PM3 & $1 / 6$ & 1 & 1 & $1 / 3$ & 1 & $1 / 3$ & 1 & $1 / 3$ \\
\hline PM4 & 4 & 1 & 3 & 1 & 1 & 4 & 1 & 3 \\
\hline PM5 & 2 & 1 & 1 & 1 & 1 & $1 / 2$ & 1 & 3 \\
\hline PM6 & 4 & 3 & 3 & $1 / 4$ & 2 & 1 & 3 & 3 \\
\hline PM7 & 1 & $1 / 3$ & 1 & 1 & 1 & $1 / 3$ & 1 & 3 \\
\hline PM8 & 3 & 3 & 3 & $1 / 3$ & $1 / 3$ & $1 / 3$ & $1 / 3$ & 1 \\
\hline \multicolumn{8}{|c|}{ Third Person } \\
\hline PM1 & 1 & 5 & 5 & 6 & $1 / 5$ & $1 / 5$ & $1 / 5$ & 6 \\
\hline PM2 & $1 / 5$ & 1 & 6 & $1 / 6$ & 1 & 1 & $1 / 3$ & 7 \\
\hline PM3 & $1 / 5$ & $1 / 6$ & 1 & $1 / 7$ & $1 / 7$ & $1 / 7$ & $1 / 7$ & $1 / 5$ \\
\hline PM4 & $1 / 6$ & 6 & 7 & 1 & $1 / 7$ & $1 / 6$ & $1 / 6$ & 6 \\
\hline PM5 & 5 & 1 & 7 & 7 & 1 & 1 & 1 & 5 \\
\hline PM6 & 5 & 1 & 7 & 6 & 1 & 1 & 1 & 6 \\
\hline PM7 & 5 & 3 & 7 & 6 & 1 & 1 & 1 & 6 \\
\hline PM8 & $1 / 6$ & $1 / 7$ & 5 & $1 / 6$ & $1 / 5$ & $1 / 6$ & $1 / 6$ & 1 \\
\hline
\end{tabular}

Table 4 Final Matrix of Sub-Criteria Project Management

\begin{tabular}{|l|l|l|l|l|l|l|l|l|}
\hline $\begin{array}{l}\text { Sub- } \\
\text { Criteria }\end{array}$ & PM1 & PM2 & PM3 & PM4 & PM5 & PM6 & PM7 & PM8 \\
\hline PM1 & 1.000 & 2.061 & 5.944 & 2.190 & 0.888 & 0.705 & 1.119 & 2.410 \\
\hline PM2 & 0.485 & 1.000 & 0.950 & 1.000 & 1.817 & 0.362 & 0.523 & 0.693 \\
\hline PM3 & 0.168 & 1.053 & 1.000 & 0.754 & 1.046 & 0.725 & 1.046 & 0.843 \\
\hline PM4 & 0.457 & 1.000 & 1.326 & 1.000 & 1.087 & 0.420 & 0.941 & 4.481 \\
\hline PM5 & 1.126 & 0.550 & 0.956 & 0.920 & 1.000 & 0.437 & 0.550 & 1.357 \\
\hline PM6 & 1.419 & 2.759 & 1.379 & 2.381 & 2.289 & 1.000 & 2.759 & 5.013 \\
\hline PM7 & 0.894 & 1.913 & 0.956 & 1.063 & 1.817 & 0.362 & 1.000 & 1.260 \\
\hline PM8 & 0.415 & 1.442 & 1.186 & 0.223 & 0.737 & 0.199 & 0.794 & 1.000 \\
\hline Sum & 5.964 & 11.778 & 13.698 & 9.530 & 10.681 & 4.211 & 8.731 & 17.059 \\
\hline
\end{tabular}

Table 5 Final Matrix of Sub-Criteria Security Operation and Strategy

\begin{tabular}{|c|c|c|c|c|c|}
\hline $\begin{array}{c}\text { Sub- } \\
\text { Criteria }\end{array}$ & SOS1 & SOS2 & SOS3 & SOS4 & SOS5 \\
\hline SOS1 & 1.000 & 1.529 & 0.759 & 2.241 & 1.651 \\
\hline SOS2 & 0.654 & 1.000 & 1.317 & 1.211 & 1.211 \\
\hline SOS3 & 1.317 & 0.759 & 1.000 & 2.080 & 1.931 \\
\hline SOS4 & 0.446 & 0.825 & 0.481 & 1.000 & 2.154 \\
\hline SOS5 & 0.606 & 0.825 & 0.518 & 0.464 & 1.000 \\
\hline SOS6 & 0.763 & 0.759 & 0.539 & 2.033 & 0.794 \\
\hline Sum & 4.787 & 5.698 & 4.614 & 9.029 & 8.741 \\
\hline
\end{tabular}

Table 6 Final Matrix of Sub-Criteria Equipment

\begin{tabular}{|c|c|c|c|}
\hline Sub-Criteria & EQP1 & EQP2 & EQP3 \\
\hline EQP1 & 1.000 & 1.186 & 1.533 \\
\hline EQP2 & 0.843 & 1.000 & 0.776 \\
\hline EQP3 & 0.652 & 1.289 & 1.000 \\
\hline Sum & 2.496 & 3.475 & 3.308 \\
\hline
\end{tabular}




\subsection{Tender Decision}

\subsubsection{Consistency Determination}

To be able to determine the weight of the criteria and sub-criteria, the consistency of the preference gathered in the previous section should be measured. The consistency ratio (CR) should be less than $10 \%$ to be categorized as consistent (Saaty \& Vargas, 2012). The calculation of consistency ratio is as follow:

$$
C R=\frac{C I}{R I}
$$

Where $\mathrm{Cl}$ is the consistency index and $\mathrm{Rl}$ is the random consistency index. $\mathrm{Rl}$ is based on the value of $\mathrm{n}$ (order matrix). Table 7 describes the value of RI based on the value of $n$.

Table 7 Random Consistency Index

\begin{tabular}{|l|c|c|c|c|c|c|c|c|c|c|}
\hline $\mathrm{N}$ & 1 & 2 & 3 & 4 & 5 & 6 & 7 & 8 & 9 & 10 \\
\hline Random consistency index & 0 & 0 & 0.52 & 0.89 & 1.11 & 1.25 & 1.35 & 1.40 & 1.45 & 1.49 \\
\hline
\end{tabular}

The calculation for the consistency index is:

$$
C I=\frac{\lambda_{\max }-n}{n-1}
$$

The value $\lambda_{\max }$ is the largest eigenvalue of the matrix. The summary of the consistency ratio calculation can be seen in Table 8

Table 8 Summary of Consistency Test

\begin{tabular}{|l|c|c|c|c|}
\hline & $\lambda_{\max }$ & $\mathrm{Cl}$ & $\mathrm{CR}$ & Remarks \\
\hline Criteria & 3.031 & 0.016 & 0.027 & Consistent \\
\hline PM Sub-Criteria & 8.710 & 0.101 & 0.072 & Consistent \\
\hline SOS Sub-Criteria & 6.280 & 0.056 & 0.045 & Consistent \\
\hline EQP Criteria & 3.030 & 0.015 & 0.026 & Consistent \\
\hline
\end{tabular}

\subsubsection{Weight Determination}

The next step is determining the weight by multiplying the eigenvector of each criterion to every eigenvector of the sub-criteria. The summary of the weight for each criterion is shown in Table 9.

\begin{tabular}{|c|c|c|c|c|c|c|c|c|c|c|c|}
\hline $\begin{array}{c}\text { Sub- } \\
\text { Criteria }\end{array}$ & $\begin{array}{c}\text { Eigen } \\
\text { Vector } \\
\text { Sub- } \\
\text { Criteria }\end{array}$ & $\begin{array}{l}\text { Eigen } \\
\text { Vector } \\
\text { PM }\end{array}$ & Weight & $\begin{array}{c}\text { Sub- } \\
\text { Criteria }\end{array}$ & $\begin{array}{l}\text { Eigen } \\
\text { Vector } \\
\text { Sub- } \\
\text { Criteria }\end{array}$ & $\begin{array}{l}\text { Eigen } \\
\text { Vector } \\
\text { PM }\end{array}$ & Weight & $\begin{array}{c}\text { Sub- } \\
\text { Criteria }\end{array}$ & $\begin{array}{c}\text { Eigen } \\
\text { Vector } \\
\text { Sub- } \\
\text { Criteria }\end{array}$ & $\begin{array}{l}\text { Eigen } \\
\text { Vector } \\
\text { PM }\end{array}$ & Weight \\
\hline PM1 & 0.191 & 0.213 & 0.041 & SOS1 & 0.210 & 0.455 & 0.096 & EQP1 & 0.402 & 0.332 & 0.133 \\
\hline PM2 & 0.087 & 0.213 & 0.019 & SOS2 & 0.175 & 0.455 & 0.080 & EQP2 & 0.287 & 0.332 & 0.095 \\
\hline PM3 & 0.089 & 0.213 & 0.019 & SOS3 & 0.222 & 0.455 & 0.101 & EQP3 & 0.312 & 0.332 & 0.103 \\
\hline PM4 & 0.117 & 0.213 & 0.025 & SOS4 & 0.128 & 0.455 & 0.058 & & 1.000 & & 0.332 \\
\hline PM5 & 0.093 & 0.213 & 0.020 & SOS5 & 0.121 & 0.455 & 0.055 & & & & \\
\hline PM6 & 0.236 & 0.213 & 0.050 & SOS6 & 0.144 & 0.455 & 0.066 & & & & \\
\hline PM7 & 0.117 & 0.213 & 0.025 & & & & & & & & \\
\hline PM8 & 0.071 & 0.213 & 0.015 & & & & & & & & \\
\hline Sum & 1.000 & & 0.213 & Sum & 1.000 & & 0.455 & Sum & 1.000 & & 0.332 \\
\hline
\end{tabular}

Table 9 Summary of Weight for Each criterion

\subsubsection{Scoring Determination \& Decision}

In scoring determination, each vendor is given a score based on the completeness of the submitted document. The procurement committee is the one that determines the score based on the score matrix that is developed 
beforehand. Once the scoring is done, then the final score of each vendor is calculated by multiplying the weight of each sub-criteria to the score given. The result of the calculation is shown in Table 10.

Table 10. Sub-Criteria Scoring of Vendor

\begin{tabular}{|l|c|c|c|c|c|c|}
\hline Sub-Criteria & Weight & Vendor A & Vendor B & Vendor C & Vendor D & Vendor E \\
\hline PM1 & 0.041 & 2.028 & 2.028 & 2.839 & 3.244 & 4.056 \\
\hline PM2 & 0.019 & 1.853 & 1.297 & 1.482 & 0.926 & 1.853 \\
\hline PM3 & 0.019 & 1.319 & 1.130 & 1.507 & 1.695 & 1.884 \\
\hline PM4 & 0.025 & 1.988 & 1.988 & 1.988 & 2.485 & 2.237 \\
\hline PM5 & 0.020 & 1.971 & 1.971 & 1.971 & 1.971 & 1.971 \\
\hline PM6 & 0.050 & 4.006 & 4.507 & 5.007 & 3.505 & 5.007 \\
\hline PM7 & 0.025 & 1.745 & 1.247 & 1.496 & 1.496 & 1.247 \\
\hline PM8 & 0.015 & 1.509 & 0.754 & 1.056 & 0.905 & 1.358 \\
\hline Sum & 0.213 & 16.418 & 14.922 & 17.347 & 16.229 & 19.612 \\
\hline Sub-Criteria & Weight & Vendor A & Vendor B & Vendor C & Vendor D & Vendor E \\
\hline SOS1 & 0.096 & 7.648 & 7.648 & 7.648 & 7.648 & 8.605 \\
\hline SOS2 & 0.080 & 6.390 & 5.591 & 4.792 & 3.993 & 7.987 \\
\hline SOS3 & 0.101 & 7.081 & 7.081 & 8.093 & 6.070 & 5.058 \\
\hline SOS4 & 0.058 & 4.077 & 4.660 & 5.242 & 5.242 & 5.242 \\
\hline SOS5 & 0.055 & 5.491 & 5.491 & 5.491 & 5.491 & 5.491 \\
\hline SOS6 & 0.066 & 6.553 & 6.553 & 6.553 & 6.553 & 6.553 \\
\hline Sum & 0.455 & 37.241 & 37.024 & 37.820 & 34.998 & 38.936 \\
\hline Sub-Criteria & Weight & Vendor A & Vendor B & Vendor C & Vendor D & Vendor E \\
\hline EQP1 & 0.133 & 6.670 & 9.339 & 13.341 & 13.341 & 13.341 \\
\hline EQP2 & 0.095 & 7.618 & 7.618 & 9.522 & 8.570 & 9.522 \\
\hline EQP3 & 0.103 & 10.347 & 10.347 & 10.347 & 10.347 & 10.347 \\
\hline Sum & 0.332 & 24.635 & 27.303 & 33.210 & 32.258 & 33.210 \\
\hline
\end{tabular}

Table 11 Total Score of Each Vendor

\begin{tabular}{|c|c|c|c|c|}
\hline \multirow{2}{*}{ Vendor } & \multicolumn{3}{|c|}{ Criteria } & \multirow{2}{*}{ Total Score } \\
\cline { 2 - 4 } & PM & SOS & EQP & \\
\hline A & 16.418 & 37.241 & 24.635 & 78.294 \\
\hline B & 14.922 & 37.024 & 27.303 & 79.250 \\
\hline C & 17.347 & 37.820 & 33.210 & 88.377 \\
\hline D & 16.229 & 34.998 & 32.258 & 83.484 \\
\hline E & 19.612 & 38.936 & 33.210 & 91.758 \\
\hline
\end{tabular}

The winner is from the vendor who received the highest total score. From Table 11, Vendor $E$ is the one who received the highest score of 91.758 . Therefore, the winner of the tender is Vendor $\mathrm{E}$.

\subsection{Current Condition and Proposed Condition}

There are some differences in the criteria and sub-criteria weight on the current condition and the proposed condition. The difference can be seen in Figure 2 and Figure 3. In the current condition, PM criteria are given a weight of 0.35 while this study proposed 0.21 ; the weight of SOS criteria in the current condition is 0.4 while this study proposed 0.46 ; the weight of EQP criteria in the current condition is 0.25 while this study proposed 0.33 .

These differences occur due to the method of determining the weight. In the current condition, the weight is determined directly by the procurement committee and the contract engineer. This method leads to huge subjectivity and is not able to accommodate the precision. Using AHP as the method to determine the weight gives a more structured framework that minimizes the subjectivity and ensures the consistency of the result. 


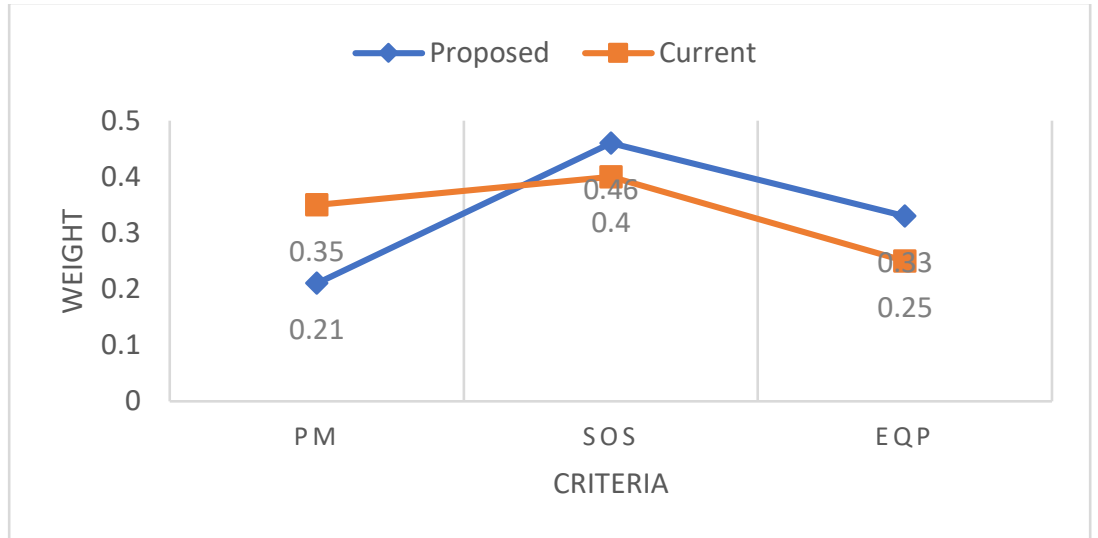

Figure 2. Weight Comparison of Criteria



Figure 3. Weight Comparison of Sub-Criteria

Since the weight of the current criteria is different from the proposed study, the total score for each vendor is also different. The difference in the total score can be seen in Figure 4. Though this difference does not affect much on the decision of the winner (Vendor $\mathrm{E}$ received a score of 91.612 in the current condition and 91.758 based on this study), the decision of the vendor with the lowest score is different. In the current decision, Vendor B is chosen as the lowest score, while in this study is Vendor A. Using the AHP method as the tools to evaluate the tender ensures the weight for the criteria and sub-criteria is according to what the company needs and the consistency of the weight can be guaranteed.

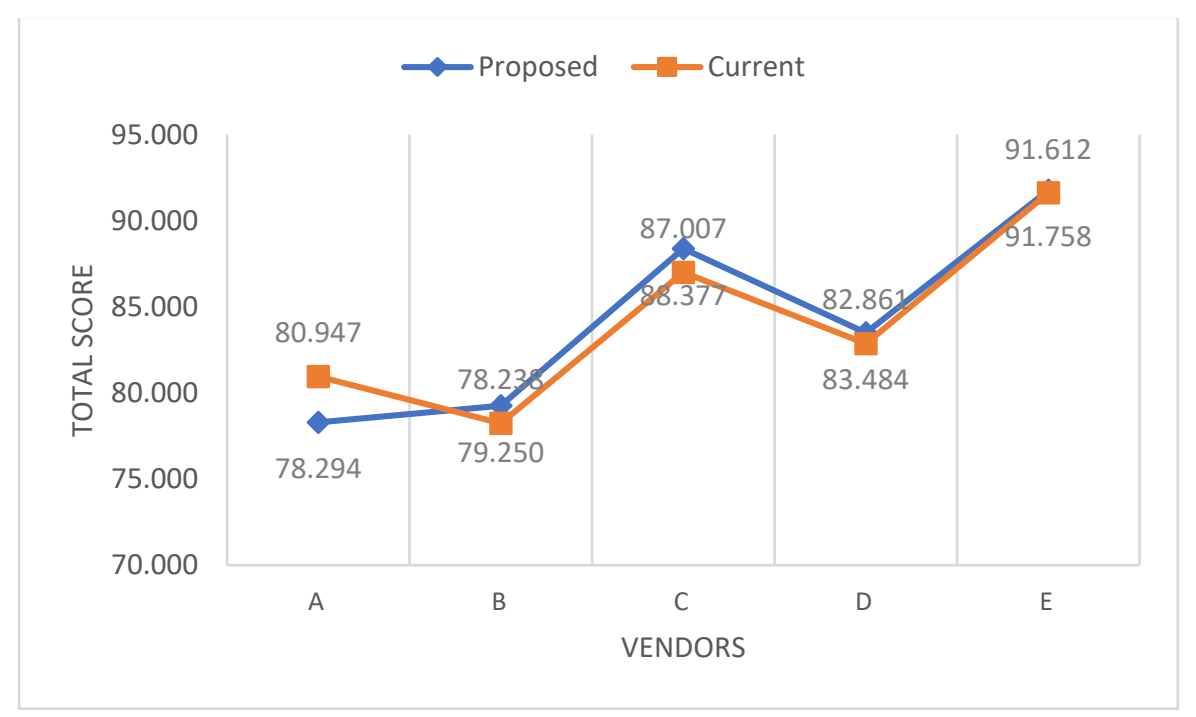

Figure 4. Vendor Total Score 


\section{Conclusion}

The conclusion of this research is:

1. The tender criteria for Security Operation in PT. $X$ are project management, security operation and strategy, and equipment.

2. The method of AHP reduces the subjectivity aspect when determining the weight of the criteria and sub-criteria by calculating the consistency ratio.

3. The winner of the tender process is Vendor $\mathrm{E}$.

The recommendation for further research is:

1. A post-qualification study should be conducted to ensure the chosen vendor is the best one.

2. Another method of decision-making tools can be used, then compared the result as a way to find a more suitable method.

\section{References}

1. Dimitri, N., Piga, G., \& Spagnolo, G. (Eds.). (2006). Handbook of procurement. Cambridge University Press.

2. Ervianto, W. I. (2005). Manajemen Proyek Konstruksi. Yogyakarta: Andi.Suprayogi. (2003). Vehicle routing problem: definition, variants, and application, Proceeding Seminar Nasional Perencanaan Sistem Industri 2003 (SPNS 2003), Bandung.

3. Ma'arif, M. Syamsul dan Hendri Tanjung. (2003). Teknik-Teknik Kuantitatif untuk Manajemen. Jakarta: Grasindo.

4. Hartanto, T., Ginting, M., \& Sunardi, O. (2019, May). A Fuzzy Analytic Hierarchy Process approach for determining the criteria success factors of MRT parts 'e-procurement: the case of Jakarta MRT project. In IOP Conference Series: Materials Science and Engineering (Vol. 528, No. 1, p. 012001). IOP Publishing.

5. Khaira, A., \& Dwivedi, R. K. (2018). A state of the art review of Analytical hierarchy process. Materials Today: Proceedings, 5(2), 4029-4035.

6. Project Management Institute. (2017). A Guide to the Project Management Body of Knowledge (Sixth Edition ed.). New Town Square: Project Management Institute.

7. Saaty, T. L., \& Vargas, L. G. (2012). Models, Methods, Concepts \& Application of the Analytical Hierarchy Process. New York: Springer.

8. Waris, M., Panigrahi, S., Mengal, A., Soomro, M. I., Mirjat, N. H., Ullah, M., ... \& Khan, A. (2019). An application of analytic hierarchy process (AHP) for sustainable procurement of construction equipment: Multicriteria-based decision framework for Malaysia. Mathematical Problems in Engineering, 2019. 